\title{
José Ramalho
}

\section{Gabriel Miranda ${ }^{1}$}

Ramalho acorda cedo e mora longe

No café da manhã, tem a companhia

de sua esposa, suas filhas

e da esperança de dias melhores

que custam chegar

No busão lotado, ele espera calado

E atravessa a cidade para trabalhar

Sessenta anos, terceirizado

Trabalhador superexplorado

Sem idade para se aposentar

Retratos de um Brasil

Que no ano de 2019

Parece só afundar

E no ônibus lotado

Ele continua a esperar

Ramalho tem nome de artista: Zé Ramalho

1 Discente do curso de Doutorado em Psicologia na Universidade Federal do Rio Grande do Norte (UFRN, Natal) e, atualmente, em estágio doutoral na École des hautes études en sciences sociales (EHESS, Paris). 
Mas na meritocrática

sociabilidade do capital

Não haveria de ter lugar ao Sol

para outro Zé Ramalho

Para um: microfones e holofotes

Para outro, que é também outros

Flanela para limpar o chão

Quando muito: arroz e feijão

A mistura? Frustração!

Tá servido o prato do peão

Para um, matérias em revistas, jornais

Programas de tevê e tudo mais

Para outro(s), salário mínimo, no máximo

e invisibilizacão. Quer não?

Tem outra opção: seu retrato estampado

em programas policiais.

Tá bom ou quer mais?

Encontro Ramalho às nove da matina

Luva na mão, joelhos no chão

Na cabeça, não sei, talvez preocupação

Um pária brasileiro, urbano

Não indiano. Ou sim, talvez. Mas não!

Ninguém se importa em saber

QUAIS SÃO SEUS SONHOS

apenas em destruí-los

Não é mesmo, seu Jair?!

Bem-vindos ao Brasil dois mil e dezenove

Que acumula em suas 500 primaveras 
longos invernos: genocídio, escravidão, ditaduras, social-liberalismo, ILUSÃO...

Ilusão... Esta palavra que

Uns carregam sem saber

$E$ outros oferecem

Ingenuamente ou

sabendo o que estão a fazer

E Ramalho continua

com afinco a limpar

o chão que pisamos

E transitamos sem

nos preocuparmos

com quem o limpa

Não sabe ele que

sua luta pela sobrevivência

É ao mesmo tempo

Uma guerra contra si

Ou sabe, talvez sem saber

Que aquele trabalho

Seu suado e sofrido trabalho

Que reza para não perder

Ao ser seu ganha pão

É, ao mesmo tempo,

uma adaga que perfura seu peito

E o mata lentamente, dia após dia. 